\title{
Positive Impacts of Covid-19 Pandemic on Various Aspects
}

Aditya Sharma*

Medicalintern, DepartmentofPreventiveandSocialMedicine,Jawaharlal Nehru Medical College, Datta Meghe Institute of Medical Sciences (Sawangi), Wardha.

Email:-sharma.adi04@gmail.com

\begin{abstract}
:
During the year 2020, our globe has faced a disastrous monster in the form of a microscopic virus. Innumerable lives have suffered across various countries and the loss is indeterminable. Sadness, grief, fear and anxiety has taken over all families of those suffering from the deadly virus. The virus has changed the outlook to most aspects. Even in the past, pandemics and infectious diseases as such have put humans in a position to initiate their world anew. The corona pandemic seems to have similar consequences. Apart from the boredom, helplessness, uncertainty of the future, nations also battle against various other issues like economic crises and climatic changes. Living through the pandemic, even though our worlds have shrunk to our house mates and our laptops, but the entire globe stands in it together fighting the common enemy. And more importantly, the pandemic has also brought in some positive changes into the lives of the people as well as on different nations as a whole. The objective of this article is to draw your attention towards the positive impacts of the Covid 19 pandemic. Despite the various drawbacks of the global pandemic, it has also helped our nation and the whole world in various ways.
\end{abstract}

Keywords: positive impact, hygiene, environment, relationships, crime

\section{Introduction:}

The corona pandemic has affected millions of lives across the globe. It has not only had a physical impact on the lives of people, but also there has been a sudden spike in the mental health issues faced by the people. As of May 5, 2020, 3665912 patients were diagnosed with the corona virus; of these, 257337 died [1]. People of all social status have been equally affected by the global pandemic. Stress, anxiety, depression and panic has affected our community in all walks of life. Not being able to attend their jobs, a sudden restriction to their outing and being stuck in a room for days had a major impact on communities throughout. There is a fear of losing jobs, savings and even basic resources like medical supplies and even groceries amongst the people. Along with this there is an accompanying constant fear of disease transmission. All of this fear and apprehension has lead to massive riots in various countries. The lockdown has also resulted in the manifestation of withdrawal symptoms among the people addicted to tobacco and alcohol. But even in this situation of the pandemic, it cannot be denied that a silver lining exists. The positive impact on global warming, which was an emerging global issue cannot be ignored. The air is cleaner, oceans are clearer and the benefit the pandemic has had on the flora and fauna is massive. The Covid19 Pandemic has been in fact a blessing in disguise in various aspects.

\section{Positive impacts: \\ Global Warming and the green house effect:}

Discoveries of the current investigation are upheld by numerous accessible sites/websites, which have detailed positive parts of lockdown, for example, improvement in air quality/mending of nature [2]. The greenhouse gas production has been drastically reduced in the wake of the pandemic. As measures taken to prevent the spread of the virus, factories have been shut, industries closed and local as well as large scale businesses closed down, and fewer vehicles on the roads. This has lead to a decrease in air pollution by $20-30 \%$ and has also lead to reduction 
in the depletion rate of the ozone layer. Even the canals and oceans have become clearer due to the great reduction in the everyday human activities. According to recent reports by NASA (National Aeronautics and Space Administration) and ESA (European and Space Agency), it is suggested that $\mathrm{NO} 2$ emission is reduced by $30 \%$. The transportation decrease is liable for the decays of $\mathrm{NO} 2$ and $\mathrm{CO}$, because of the limitation of human versatility (e.g., vehicle utilize diminished in all urban communities during lockdown, and the decreased power utilization is answerable for the decline of SO2 because of the limitations of modern and business exercises [3] [4].

Humankind withdraws inside and the nonhuman characteristic world thunders out freed. Famously grimy, the streams and waterways on the planet look cleaner, the air fresher, the exhaust cloud gone, the fog scattered and the natural life has occupied the open spaces, Covid lockdowns across the world appear to have various beneficial outcomes on the climate. A great many the individuals have been cooped up inside yet the common world outside has kept on thundering on and the regular world is profiting by our nonattendance. Here, we have examined some significant positive effects of the COVID-19-instigated lockdown on ecological quality by ordering the as of late distributed information from research articles, NASA (National Aeronautics and Space Administration) and ESA (European Space Agency).

Ozone depleting substance emanations and contamination levels the nation over have fallen altogether. A large portion of a year prior Delhi was panting for a much needed refresher saw "emphatically snowcapped" air quality two or three days back. Delhi is presently getting a charge out of one of the least air contamination levels found in the previous decade or more. The equivalent is valid for other metropolitan urban areas like Mumbai and Kolkata.

\section{Hygiene and sanitation:}

In the height of the pandemic, people are finally starting to realize the importance of self-cleanliness. As human beings, social distancing can be frustrating to most of us at a point. Though this pandemic though, people have realized the importance of maintaining distance even in daily lives to combat the spread of deadly infectious creatures to some extent.Hand cleanliness was advanced in late January, and a huge increment of Google looks for "washing hands" was seen since January 19, 2020 [5].

From shaking hands to namaste, we as a whole have had a way of life change for the great. From covering our mouths while coughing to sterilizing our hands at regular interval, every small act can make a great difference in combating the spread of the deadly virus.

At the individual level, people have started washing their hands more regularly and keeping basic hygiene in mind. Even the governments and autonomous organizations are taking special measures to keep the surroundings clean. The importance of personal and community hygiene has become more highlighted. This habit of incorporating personal hygiene into daily lives will stay with the people even after the pandemic has ended. People are more likely to clean and sanitize surfaces more frequently.

\section{Decreased Accidents and Crime rate:}

The number of road traffic accidents has majorly reduced due to the lockdown. Lesser vehicles on road in an attempt to contain the spread of the virus. Avoidance of unnecessary traveling and meetings has also played a role. The economic costs associated with traveling has also greatly reduced. The morbidity and mortality rate has reduced in most countries in the wake of the pandemic. Recent studies have even proved that the crime rate has drastically reduced due to the lockdown. Assault, murders, rapes and robberies have also greatly reduced. 
constraining everybody to receive computerized in all things - from purchasing goods to looking for online meetings with a specialist for minor conditions.

\section{Greater investment in health care facilities:}

Countries like Columbia which initially had only around 5000 ICUs in the year 2019 has now increased its number to 7000 in the need of the hour. The number of ventilators, emergency facilities and respiratory care equipment has also greatly increased. The general public has also greatly realized the importance of health care facilities and health care providers. The violence against doctors has also significantly reduced at a large scale.

\section{Private sector helping the cause:}

With the economy falling and the government not being able to fulfill the demands of the hour, the private sectors have been of great help. Switching to the production of various need of the hour including sanitizers, masks, hand gloves is being done by various small and large scale companies. They have also aided the government by providing donations in the form of money and essentials. For example, in countries like Nigeria, the private sectors have been the most helpful by building up hospitals, providing essentials like ventilators have been of great helpful.

\section{Helps build genuine relationships:}

We all in all have been so clamoring living the 'life,' countless us have lost those certified, genuine minutes we have with our loved ones. It may have been the clamoring schedules, heading over to get by, and rushing to be in squeezing social occasions.

Obviously, maybe you were enough blessed to go for family voyages every now and by then. However, and, all things considered, didn't you dread those impending archives holding up at your workstation?
By and by, the COVID-19 situation has unequivocally influenced the way wherein you carry on and take care of associations. You will contribute your energy with your family and plan your work better. This truly causes you gather a predominant future for both your work and family.

As life moved down, we have found ways to deal with remain related with people, whether or not it's fundamentally. Reconnect with your loved ones and knowing the past.

Not being occupied by work and meetings all day long, the working class has found time to spare for the family and friends in the midst of the pandemic. Staying home for longer hours with their loved ones has increased the strength of the bond they share and provided more time that they can spare for the family and loved ones.Parents ended up spending more quality time with their children will also result in better upbringing of their children.

The pandemic has led to causing individuals to acknowledge estimation of re-interfacing with families[8] and improvement in affection/dating and family relationships.[9] However, the improved relationship measurements could likewise be ascribed to the way that, when everybody is battling a shared adversary, the relational relationship issues are failed to remember, which is perhaps reflected as improved relationships.[10,11] Another clarification for the improved relationship could be a dread of death, which regularly causes individuals to see themselves as powerless, and henceforth, have less activity to battle with others.[12]

\section{Individual basis:}

The pandemic has cut down unnecessary expenses on transportation, eating outside in restaurants, traveling, entertainment etc. It has incorporated healthier eating habits among people, as the restaurants getting shut down in the lockdown and the risk of transmission of the virus and the fear of the crowd has made people switch to healthier home cooked food. 
It has also helped people to spend more time with oneself, focusing on themselves, take out more time for their own hobbies, developing skills like gardening, reading, cooking, dancing etc. People have all invested more time in healthier activities like spirituality, meditation, yoga, workouts which will eventually be helpful in the longer run.

The complexity of disasters will be better understood, triggering higher preparedness levels.

Government has had more time to develop preparedness for disasters like earthquakes, floods, cyclones, landslides and various others faced by different nations. It has given the nations ample of time to research into the preparedness level of the countries and has hence become aware of their disaster management schemes. We know from past examinations that movement limitations have exhibited a beneficial outcome in past SARS, Ebola and bubonic plague episodes $[13,14,15]$.

\section{Boosting Localism:}

Effectively essential to manageability cognizant buyers, brands' sourcing and creation procedures will turn into a more significant factor for standard customers. Everywhere on the world, customers are presently more for items that are have been created locally. $65 \%$ of individuals favor purchasing merchandise and ventures from their own nation. This increments for the individuals who see themselves as supportability dynamic $(79 \%)$ or connected with $(72 \%) .42 \%$ of buyers state they presently give more consideration to the cause of items. In family units with youngsters this increments to $52 \%$. One of every four buyers think the brands they use ought to take creation back to their own nation, while one out of three concern whether they are at a danger from items sent from abroad. Items from China and the US, specifically, are seen as hazardous by individuals in different nations with $60 \%$ and $47 \%$ separately saying they are marginally/far less for purchasing products and enterprises from those nations [16-18]. China has been the processing plant of the world for a long while now and subsequently it has become the mainstay of worldwide stock chains for everything from chips to sedate APIs. The world has understood that it probably won't be a smart thought to place all investments tied up on one place. This would imply that nations like India that have since quite a while ago trusted that their turn will make for the world would progressively see more unfamiliar organizations set up base and create enormous scope business[1921]. This can be a boon to the Indian economy. Through this, small scale and local Indian brands have been given a great opportunity in flourishing during the pandemic[22,23]. This has also given a boost to the Make in India Campaign, which further promotes companies to invest and manufacture in India and further increasing incentives dedicated to investments and manufacturing [24-26].

\section{Conclusion:}

Every single possible measure is being taken by all countries to combat the spread of the virus, but this has forced individuals to change the habits like from shaking hands daily to leaving homes for an outing. Borders have been enforced across nations and travel is not the same during this pandemic war. Response to the virus has also been very emotionally charging as anxiety and fear has shook the public across the globe. The emotional disturbance that the lockdown has caused the people will accompany other long lasting effects of the pandemic like the economic loss. These changes will stay with us far after the medical emergency has died down, affecting our community and its outlook in innumerable ways. The need of the hour is to keep our minds positive individually and do our maximum and best in fighting the virus so that we can emerge victorious 


\section{References:}

1. Dong E, Du H, Gardner L. An interactive web- based dashboard to track COVID- 19 in real time. Lancet Infect Dis. 2020;20(5):533-534. 10.1016/S14733099(20)30120-1

2. India's Coronavirus Lockdown is Having a Dramatic Impact on Pollution - CNN. [Last accessed on 2020 Apr 28]. Available from:

https://editioncnncom/2020/03/31/asia/cor o navirus-lockdown-impact-pollutionindia-intl-hn k/indexhtml

3. Apple Mobility Trends Reports. Available online:

https://www.apple.com/covid19/mobility (accessed on 31 July 2020).

4. International Energy Agency (IEA). Global Energy Review 2020: The Impacts of the COVID-19 Crisis on Global Energy Demand and $\mathrm{CO} 2$ Emissions, Flagship Report-April 2020. Available online: https://www.iea.org/reports/global-energyreview-2020/electricity (accessed on 31 July 2020).

5. Lin Y, Liu C, Chiu Y. Google searches for the keywords of "wash hands" predict the speed of national spread of COVID-19 outbreak among 21 countries. Brain BehavImmun 2020 Jul;87:30-32

6. "Crime and Contagion: The impact of a pandemic on organized crime". Global Initiative. 2020-03-26. Retrieved 2020-0412

7. (March 2020) Crime and Contagion: The impact of a pandemic on organized crime. POLICY BRIEF. Global Initiative Against Transnational Organized Crime. Retrieved on 12 April 2020.

8. Foster O. 'Lockdown made me Realise What's Important': Meet the Families Reconnecting Remotely The Guardian. 2020. [Last accessed on 2020 Apr 28]. Available from: https://wwwtheguardiancom/keepconnected/2020/apr/23/lockdown-mademe-realise-whats-important-meet-the-fa milies-reconnecting-remotely .

9. Bilefsky D, Yeginsu C. Of 'Covidivorces' and 'Coronababies': Life During a Lockdown. N Y Times. 2020. [Last accessed on 2020 Apr 28]. Available from: https://wwwnytimescom/2020/03/27/world /corona virus-lockdown-relationshipshtml .

10. Sullivan D, Landau MJ, Rothschild ZK. An existential function of enemyship: Evidence that people attribute influence to personal and political enemies to compensate for threats to control. J Pers Soc Psychol. 2010;98:434-49. [PubMed] [Google Scholar]

11. Bosson JK, Johnson AB, Niederhoffer K, Swann WB. Interpersonal chemistry through negativity: Bonding by sharing negative attitudes about others. PersRelatsh. 2006;13:135-50. [Google Scholar]

12. Mikulincer M, Florian V, Birnbaum G, Malishkevich S. The death-anxiety buffering function of close relationships: Exploring the effects of separation reminders on death-thought accessibility. Pers Soc Psychol Bull. 2002;28:287-99. [Google Scholar]

13. Camitz M, Liljeros F. The effect of travel restrictions on the spread of a moderately contagious disease. BMC Med 2006; 4:32

14. Peak CM, Wesolowski A, ZuErbachSchoenberg E et al. Population mobility reductions associated with travel restrictions during the Ebola epidemic in Sierra Leone: use of mobile phone data. Int J Epidemiol 2018; 47:1562-70.

15. Bowers KW. Balancing individual and communal needs: plague and public health in early modern Seville. Bull Hist Med 2007; 81:335-58.

16. "Look East, Link West, says PM Modi at Make in India launch". Hindustan Times. 25 September 2014.

17. AnjankarAshish, P., P. AnjankarVaibhav, J. Anjankar Anil, and K. Lata. "Positive Aspects of Covid 19 Pandemic: A Blessing in Disguise." International Journal of Research in Pharmaceutical Sciences 11, no. Special Issue 1 (2020): 187-91. https://doi.org/10.26452/ijrps.v11iSPL1.23 71.

18. Borage, S., and P. Shelotkar. "Positive Effects of Covid-19 on Earth." International Journal of Research in 
Pharmaceutical Sciences 11, no. Special Issue $\quad 1 \quad$ (2020): 234-38. https://doi.org/10.26452/ijrps.v11iSPL1.27 04.

19. Kamdi, P.S., and M.S. Deogade. "The Hidden Positive Effects of Covid-19 Pandemic." International Journal of Research in Pharmaceutical Sciences 11, no. Special Issue 1 (2020): 276-79. https://doi.org/10.26452/ijrps.v11iSPL1.27 12.

20. Srivastava, R., N. Rathi, N. Thosar, S. Baliga, M. Khubchandani, V. Mohite, J. Mehta, and R. Waykar. "Contemporary Treatment Modalities for the Management of SARS-CoV-2 Positive Patients: An Overview." International Journal of Research in Pharmaceutical Sciences 11, no. Special Issue 1 (2020): 839-46. https://doi.org/10.26452/ijrps.v11iSPL1.30 90.

21. Budhrani, A.B. "A Review: Coronavirus, Its Types, and Impact of Covid-19 on Global Wealth." International Journal of Research in Pharmaceutical Sciences 11, no. Special Issue 1 (2020): 455-61. https://doi.org/10.26452/ijrps.v11iSPL1.28 11.

22. Kothari, L., S. Wadatkar, R. Taori, P. Bajaj, and D. Agrawal. "Coronavirus: Towards Controlling of the PandemicIndian Scenario." International Journal of Research in Pharmaceutical Sciences 11, no. Special Issue 1 (2020): 462-68. https://doi.org/10.26452/ijrps.v11iSPL1.28 13.

23. Lohiya, S.B., S. Damke, and R. Chaudhary. "Coronavirus Disease
(COVID) 2019 in Children - A Short Review." International Journal of Current Research and Review 12, no. 17 (2020): 172-77.

https://doi.org/10.31782/IJCRR.2020.1217 26.

24. Parwe, S.D., M.A. Nisargandha, and R. Thakre. "Role of Convalescent Plasma Therapy in New Coronavirus Disease (Ncovid-19): A Review." International Journal of Research in Pharmaceutical Sciences 11, no. Special Issue 1 (2020): 546-49. https://doi.org/10.26452/ijrps.v11iSPL1.28 46.

25. Rathi Saurabh, D., P. Nikhade, N. Motwani, S. Baror, and A. Jaiswal. "Coronavirus Pandemic-the Real Lessons Are Learnt in the Time of Crises." International Journal of Research in Pharmaceutical Sciences 11, no. Special Issue 1 (2020): 1011-14. https://doi.org/10.26452/ijrps.v11iSPL1.34 26.

26. Darwate, T., and S. Hiware. "Concept of Rasayana Therapy in Covid 19." International Journal of Research in Pharmaceutical Sciences 11, no. Special Issue 1 (2020): 857-61. https://doi.org/10.26452/ijrps.v11iSPL1.30 93. 